\title{
PENGUATAN HAK ASASI PEREMPUAN DAN KESETARAAN GENDER MELALUI DIALOG WARGA
}

\author{
Anila Umriana, Moh. Fauzi, Hasyim Hasanah \\ Universitas Islam Negeri (UIN) Walisongo Semarang \\ e-mail: anila.umriana@yahoo.com, fauzi_umma@yahoo.com, \\ hasyimhasanah_82@yahoo.co.id
}

\begin{abstract}
Abstrak
Tulisan ini menjelaskan penguatan hak asasi perempuan dan kesetaraan gender melalui dialog warga di kelurahan Gisikdrono Kec. Semarang Barat Kota Semarang. Tulisan ini merupakan hasil program pengabdian yang diarahkan pada munculnya kesadaran warga mengenai hak asasi perempuan dan kesetaraan gender. Hasil kegiatan pendampingan menunjukkan bahwa masih terdapat problem pemahaman dan kesadaran hak asasi perempuan dan kesetaraan gender di masyarakat. Ini dibuktikan dengan masih banyaknya ketidakadilan gender berupa diskriminasi, subordinasi, beban ganda yang dibebankan kepada perempuan. Upaya yang digunakan untuk mningkatkan kapasistas kesadaran hak asasi perempuan dan kesetaraan gender melalui dialog warga. Metode pengabdian menggunakan prinsip dialog warga. Model dialog warga bertujuan untuk mengembangkan kompetensi komunitas dalam menangani isu hak asasi perempuan dan kesetaraan laki-laki dan perempuan yang mereka anggap paling penting. Salah satu pinsip dasar dialog warga selalu berbasis kepada hak asasi, kesetaraan, apresiatif, berbasis asset masyarakat, memberdayakan, berkelanjutan, berorientasi perubahan, menggunakan bahasa istilah lokal, dan bukan merupakan proyek. Peningkatan kapasitas hak asasi perempuan dan kesetaraan gender dilakukan mendasarkan pada siklus dialog warga. Hasil akhir program menunjukkan bahwa telah terbentuk kesadaran dan pemahaman mengenai hak asasi perempuan, dan kesetaraan gender di masyarakat.
\end{abstract}

Kaat Kunci: penguatan; hak asasi perempuaan; kesetaraan gender; dialog warga

\section{A. Pendahuluan}

Masayarakat semakin resah dan prihatin dengan meningkatnya pemberitaan media mengenai kasus kekerasan terhadap perempuan dan anak. Mulai dari kasus penganiayaan, pemerkosaan, pembunuhan, hingga kasus 
mutilasi yang menimpa kaum perempuan. Data kekerasan Perempuan dan Anak meningkat dari tahun ke tahun. Komnas perempuan menyebutkan bahwa, terdapat trend kenaikan jumlah kasus kekerasan terhadap perempuan dan anak. Jumlah kekerasan terhadap perempuan dan anak secara umum dapat dilihat dari tahun 2010 dengan total kasus sebesar 101.128. Tahun 2011 total kekerasan dalam rumah tangga (KDRT) sebesar 12.999, dan Kekerasan Terhadap Anak dan Perempuan (KTPA) sebesar 660. Pada tahun 2012 total kasus KDRT 13.771, dan KTAP 1311. Tahun 2013 tercatat kasus kekerasan sebanyak $211.131{ }^{1}$

Sumber lain menjelaskan peningkatan kasusu kekerasan juga terjadi pada tahun 2014. Data Komnas PRPA tahun 2014 sebagaimana dilansirr detik.com berjumlah 279.760 kasus 0. ${ }^{2}$ Women Crisis Centre (WCC) menyebutkan pada Tahun 2014 terdapat 293.220 kasus kekerasan terhadap perempuan dan anak peningkatan kasus kekerasan juga terjadi pada tahun 2015 sebanyak 321.752 atau meningkat 9 (sembilan) persen dari tahun 2014 (sumber WCC dalam Kompas.com). Semakin tingginya kasus kekerasan terhadap perempuan dan anak ini menunjukkan Indikasi bahwa telah terjadi pelanggaran hak asasi manusia.

Pelanggaran hak asasi manusia salah satunya dtunjukkan dengan adanya tindak kekerasan, penganiayaan, perlakuan tidak adil kepada pihak lain, dan kesewenang-wenangan. Meningkatnya kasus kekerasan terhadap perempuan dan anak diduga disebabkan karena adanya beberapa faktor, baik yang bersifat internal maupun eksternal. Faktor yang bersifat internal seperti rendahnya pemahaman dan kesadaran, serta belum adanya nilainilai kesetaraan gender di masyarakat. Terjadinya kasus kekerasan berbasis gender tersebut menunjukkan terjadinya pelanggaran hak asasi perempuan dan tidak adanya nilai kesetaraan gender di Kelurahan Gisikdrono. Oleh karena itu pendampingan untuk penguatan hak asasi perempuan dan kesetaraan gender di kelurahan ini merupakan sesuatu kebutuhan yang mendesak yang harus dilakukan. Mendasarkan hal itu maka, melalui program pengabdian dan pendampingan kepada masyarakat ini, kami mendesain program mendasarkan pada aspek kebutuhan dan partisipasi warga. Kondisi ini dapat membantu warga menjadi masyarakat yang handal,

${ }^{1}$ Komnas perempuan, 2014, diakses 15 Maret 2016.

${ }^{2}$ www.detik.com, diakses 15 Maret 2016. 
berkualitas, memiliki kemandirian membangun aspek kesadaran dan pemahaman tentang gender, dan selanjutnya membuat mereka berdaya memaksimalkan potensi sosial kemanusiaan dan berkiprah dalam pembangunan secara aman, dan penuh dengan semangan kesetaraan.

Agar pembangunan mempunyai hasil berkelanjutan, maka alternatif metode yang relevan adalah metode dialog warga. Masing-masing komponen memainkan peran penting dalam keberhasilan program. Adapun daur program meliputi kegiatan penjajakan kebutuhan, perencanaan, pelaksanaan, pemantauan, dan evaluasi kegiatan, selanjutnya kembali pada siklus berikutnya.

\section{B. Konsep Hak Asasi Perempuan dan Kesetaraan Gender}

Pemahaman atas konsep gender sangatlah diperlukan mengingat dari konsep ini telah lahir suatu analis gender. Gender memiliki arti yang beragam, baik secara etimologi maupun terminologi. Pengertian secara etimologi mengenai gender, terdapat dalam bahasa Latin yaitu Genus yang berarti tipe tau jenis. Kata gender dalam bahasa Indonesia dipinjam dari bahasa Inggris Gender berarti jenis kelamin. ${ }^{3}$ Arti yang diberikan tidak secara jelas dibedakan pengertian jenis kelamin dan gender. Untuk memahami konsep gender harus dibedakan pengertian kata gender dengan jenis kelamin (seks).

Gender dalam Webstr's New Word Dictionary sebagaimana diungkapkan Esha dalam Maba berarti perbedaan yang tampak antara laki-laki dan perempuan dilihat dari segi nilai dan tingkah laku. ${ }^{4}$ Pengertian gender dalam khazanah ilmu sosial mengacu pada perbedaan-perbedaan antara laki-laki dan perempuan tanpa konotasi yang bersifat biologis. Perbedaan laki-laki dan perempan itu merupakan bentukan sosial, yakni perbedaan yang tetap muncul meskipun tidak disebabkan oleh perbedaan biologis yang menyangkut jenis kelamin. Pengertian lain mengenai gender terdapat dalam Women's Studies Encyclopedia dijelaskan bahwa gender dipahami sebagai konsep kultural yang berupaya membuat perbedaan antara laki-laki dan per-

${ }^{3}$ Ghufron Maba, Kamus Lengkap Inggris Indonesia, (Surabaya: Terbit Terang, th.), h. 12; lihat juga dalam John M.Echols, Hasan Shadily, Kamus Inggris-Indonesia, (Jakarta: Gramedia, 1995), h. 265.

${ }^{4} \mathrm{Ibid}$. 
empuan yang berkembang dalam masyarakat baik dalam hal peran, perilaku, mentalitas maupun karakteristik emosional. ${ }^{5}$

Kata gender digunakan berbeda dengan sex. Gender digunakan untuk mengidentifikasi perbedaan laki-laki dan perempuan dari segi sosial-budaya. Sementara sex digunakan untuk mengidentifikasi perbedaan laki-laki dan perempuan dari segi anatomi biologi. Istilah sex lebih banyak berkonsentrasi pada aspek biologi seseorang, meliputi perbedaan komposisi kimia dan hormon dalam tubuh, anatomi fisik, reproduksi, dan karakteristik biologis lainnya. Sementara itu, gender lebih mengarah pada jenis kelamin sosial, bukan jenis kelamin secara kodratiah.

Gender menurut beberapa ahli lebih mengarah pada sebuah konstruksi budaya atas peran yang berlaku secara sosial. Yasir Alami mengistilahkan gender sebagai atribut yang diletakkan, dikodifikasikan, dan dilembagakan secara sosial maupun kultural kepada laki-laki maupun perempuan. ${ }^{6}$ Engels dalam Narwoko dan Suyanto (2010) memahami gender sebagai sebuah perbedaan yang memenpatkan peran laki-laki dan perempuan terjadi melalui proses yang sangat panjang, melalui proses sosialisasi, penguatan, dan konstruksi sosial, kultural, dan keagamaaan bahkan melalui kekuasaan negara. Proses panjang itulah, maka lama-kelamaan perbedaan gender antara laki-laki dan perempuan menjadi seolah-olah ketentuan Tuhan atau sifat kodratiah yang tidak dapat diubah dan dipertukarkan lagi. Demikian pula sebaliknya, sosialisasi konstruksi sosial tentang gender secara evolusi pada akhirnya memengaruhi perkembangan fisik dan biologis masingmasing jenis kelamin. ${ }^{7}$

Lips menyebutkan bahwa gender lebih tepat diartikan sebagai harapanhatapan budaya bagi laki-laki dan perempuan. ${ }^{8}$ Nugroho menyebutkan bahwa gender merupakan reposisi peran sosial laki-laki dan perempuan dalam kehidupan manusia yang dikonstruksikan oleh pandangan budaya

\footnotetext{
${ }^{5}$ Mudjia Rahardjo, Relung-Relung Bahasa, (Yogyakarta: Aditya Media, 2002), h. 138.

'Yasir Alami, Jenis Kelamin Tuhan, (Yogyakarta: Yayasan Kajian dan layanan Informasi untuk Kedaulatan Rakyat, 2002), h. 3.

7J. Dwi Narwoko dan Bagong Suyanto, Sosiologi Teks Pengantar dan Terapan, (Jakarta: Kencana, 2010), h. 335. 1993), h. 4.

${ }^{8}$ H.M. Lips, Sex and Gender; an Introductions, (California: Mayfield Publishing Company,
} 
suatu masyarakat. ${ }^{9}$ Trianto menyebutkan bahwa gender sebagai perbedaanberbedaan sifat, peranan, fungsi, dan status antara perempuan dan laki-laki yang tidak berdasarkan pada berbedaan jenis kelamin, tetapi relasi sosial budaya yang dipengaruhi struktur masyarakat. ${ }^{10}$ Fauzie menjelaskan bahwa gender dipahami sebagai model hubungan sosialyang terorganisasi antara perempuan dan laki-laki, yang tidak hanya sebatas pada hubungan personal ataupun kekeluargaan, melainkan institusional dan sosial dalam skala lebih luas seperti hubungan hierarkis yang terdapat dalam suatu organisasi ataupun struktur pekerjaan. ${ }^{11}$ Pandangan sama dikemukakan oleh Steal yang menyebutkan bahwa gender bukan semata-mata ditujukan untuk membedakan perempuan dan laki-laki secara biologis, namun merupakan hubungan idiologis dan material mengenai eksistensi keduanya. Mendasarkan dari beberapa pengertian di atas dapat dirangkum bahwa gender merupakan konsep kultural yang membedakan antara perempuan dan lakilaki dipandang dari sosial budaya yang dapat dirubah dan dipertukarkan sesuai dengan perkembangan zaman.

Mendasarkan pada beberapa pengertian di atas maka ada beberapa ungkapan mengenai gender terdapat dalam modul Kesetaraan dan Keadilan Gender (KKG) Menteri Pemberdayaan Perempuan yang akan lebih memberikan pemahaman dan kesadaran gender, yaitu:

1. Departemen Tenaga Kerja dan transmigrasi menyebutkan bahwa Laki-laki dan perempuan sesuai dengan peranan dan fungsinya di dalam keluarga, sosial juga ditambahkan bahwa gender adalah perbedaan status antara laki-laki dan perempuan.

2. Departemen Agaman menuyebutkan bahwa Gender pada dasarnya merupakan konsep yang membedakan antara lakilaki dan perempuan bukan berdasarkan biologisnya, melainkan dikaitkan dengan peran, fungsi, hak, sifat, perilaku yang direkayasa sosial. Oleh karena itu, pemahaman tentang gender dapat berubah dan sangat tergantung pada budaya setempat yang mendukung.

${ }^{9}$ Rian Nugroho, Gender dan Strategi Pengarustamaan di Indonesia, (Yogyakarta: Pustaka Pelajar, 2008), h. 24.

${ }^{10}$ Teguh Trianto, “Relasi Gender dalam Bingkai Budaya Cablaka", Yinyang, Vol. 7, No. 2, Juli-Desember 2012, h. 282.

${ }^{11}$ Ridjal Fauzie, Dinamika Gerakan Perempuan di Indonesia, (Yogyakarta: Tiara Kencana, 1993), h. 29. 
3. Departemen Dalam Negeri menyebutkan bahwa gender dipakai dalam penerapan keadilan dan kesetaraan gender dalam bentuk kemitrasejajaran pria dan wanita untuk ikut serta dalam setiap aspek pembangunan. ${ }^{12}$

Pemahaman gender yang terdapat di beberapa modul pelatihan KKG pada Menteri Pemberdayaan perempuan menurut Rahmadewi mampu memberikan indikator bahwa gender erat kaitannya dengan kersoalan kesetaraan atau persamaan. Persamaan kesempatan kerja antara laki-laki dan perempuan, persamaan status sosial dalam kesempatan kerja dengan memperhatikan perbedaan kodrat perempuan seperti hamil, melahirkan dan menyusui, serta persamaan dalam hukum, politik, sosial, dan budaya. ${ }^{13}$

Pemahaman selanjutnya mengenai kesetaraan. Kesetaraan berasal dari kata setara yang berarti setingkat atau seimbang. Kesetaraan dalam pemahaman ini berarti menunjuk pada kondisi yang seimbang dan sederajat, atau sejajar. Kesetaraan juga berarti tidak berat sebelah. Kesetaraan juga berarti persamaan dan kesederajatan. ${ }^{14}$ Kesetaraan gender berarti kesamaan kondisi bagi laki-laki dan perempuan untuk memperoleh kesempatan serta hak-haknya sebagai manusia, agar mampu berperan dan berpartisipasi dalam kegiatan politik, hukum, ekonomi, sosial budaya, pendidikan dan pertahanan dan keamanan nasional (hankamnas), serta kesamaan dalam menikmati hasil pembangunan tersebut. Kesetaraan gender juga meliputi penghapusan diskriminasi dan ketidak adilan struktural, baik terhadap lakilaki maupun perempuan..$^{15}$

${ }^{12}$ Buku Referensi Pelatihan: Fakta dan Indikator Gender Tingkat Nasional, 4 Propinsi dan 16 Kabupaten/Kota Terpilih, Kementerian Pemberdayaan Perempuan, JICA dan UNFPA, 2003; lihat dalam Modul Pelatihan, Keadilan dan Kesetaraan Gender untuk BUMN/BUMD dan Perusahaan Swasata Menteri Negara Pemberdayaan Perempuan, Deputi Bidang Kesetaraan Gender bekerjasama dengan Bangun Mitra Sejati, 2001; Buku 1, Bahan Informasi Pengarusutamaan Gender, Edisi ke-2, Apa Itu Gender, Menteri Negara Pemberdayaan Perempuan RI, 2002; Buku 2, Bahan Informasi Pengarusutamaan Gender, Edisi ke-2, Bagaimana Mengatasi Kesenjangan Gender, Menteri Negara Pemberdayaan Perempuan RI, 2002.

${ }^{13}$ Rachmadewi, dkk., "Studi Evaluasi Pelaksanaan Program Kesetaraan dan Keadilan Gender (KKG) Sektoral di Tingkat Pusat, Propinsi Jawa Timur dan Sumatera Barat", Laporan Penelitian, Puslitbang KS dan Peningkatan Kualitas Perempuan, Jakarta, BKKBN, 2000, h. 41.

${ }^{14}$ Lutfiyah, "Gender dan Makna Persamaan", SAWWA Jurnal Studi Gender dan Anak, Vol. 4, No. 1, Oktober 2010, h. 52.

${ }^{15}$ Vera A. R. Pasaribu, "Kesetaraan dan Keadilan Gender", Laporan Penelitian, FISIP Universitas HKBP Nommensen, Medan, 2006, h. 8. 
Banyak upaya yang dilakukan oleh aktivis perempuan untuk memperjuangkan kesetaraan gender antara laki-laki dan perempuan. Konsep kesetaraan ini secara khusus mengarah pada persamaan kedudukan manusia diantaranya dalam kehidupan, pengajaran, mengemukakan pendapat. Hak kehidupan merupakan hak bagi semua manusia untuk dilindungi dan hak hidup secara aman dengan harta yang dimiliki. Hak kehidupan ini juga berkaitan dengan hak seseorang untuk mendapatkan jaminan dari sesuatu yang mengancam seseorang hingga melibatkan proses hukum yang baik dan benar. ${ }^{16}$ Lebih lanjut dijelaskan bahwa kesetaraan yang manusia dapatkan dalam relasi sosial diantaranya berkaitan dengan semua hak-hak yang melekat bagi setiap individu sebagai warga sipil, diantaranya mendapatkan kebebasan, kemerdekaan, keamanan, jaminan hukum, pengajaran, pendidikan, mengemukakan hak.

Kesetaraan yang berarti persamaan, kesejajaran dalam konteks gender berarti kondisi kondisi yang seimbang, sama, sejajar, satu kedudukan, dan tidak berat sebelah kaitannya dengan relasi antara perempuan dan laki-laki dalam format dan konstruksi sosial dan budaya. Kesetaraan gender tentu menjadi bagian penting dalam perwujudan hak asasi bagi perempuan. Tujuan mengenali perbedaan gender sebagai sesuatu yang tidak tetap, memudahkan untuk membangun gambaran tentang realitas relasi laki-laki dan perempuan yang dinamis, tepat, dan sesuai kenyataan yang berkembang dalam masyarakat. Hubungan gender selanjutnya adalah hubungan sosial antara laki-laki dan perempuan yang bersifat saling membantu atau sebaliknya, serta memiliki banyak perbedaan dan ketidaksetaraan. Hubungan gender berbeda dari waktu ke waktu dan antara masyarakat satu dengan masyarakat yang lain terjadi akibat perbedaan suku, agama, status sosial maupun nilai (tradisi dan norma yang dianut). Perbedaan konsep gender secara sosial telah melahirkan perbedaan peran perempuan dan laki-laki dalam masyarakatnya. Secara umum adanya kesadaran gender telah melahirkan pemahaman bahwa laki-laki dan perempuan memiliki peran, tanggung jawab, fungsi dan bahkan ruang tempat dimana manusia beraktivitas, dengan segala potensi dan keahlian masing-masing secara seimbang, setara dan sederajat.

\footnotetext{
${ }^{16}$ Murtadha Muthahari, Hak-hak Perempuan dalam Islam, (Jakarta: Lentera, 1995), h. 59; Lihat juga M. Nasarudin al-Bani, Ringkasan Shahih Muslim, (Jakarta: Gema Insani Press, 2005), h. 484 .
} 


\section{Pembahasan dan Analisis}

Kelurahan Gisikdrono merupakan salah satu kelurahan yang berada di Kecamatan Semarang Barat, yang memiliki luas wilayah 114.25 Ha. Terdiri dari 101 RT dan 13 RW dengan jumlah penduduk 20.935, laki-laki 10.627 jiwa dan perempuan 10.308 jiwa. Adapun jumlah keluarga/rumah tangga yaitu 4.760 rumah tangga dan 1 WNA. Dilihat dari penganut agamnya, terdapat tercatat 15.085 beragama Islam, 3.398 Katholik, 1.621 Protestan, 134 Budha, dan 645 Hindu. Di kelurahan Gisikdrono terdapat 12 masjid, 14 mushala, dan 6 gereja (Data Laporan Bappeda, 2011). Melihat luasnya wilayah kelurahan Gisikdrono tersebut tidak memungkinkan untuk melakukan pendampingan pada semua warga yang ada, karena itu dalam pendampingan ini difokuskan pada kelompok Jamaah Majlis Taklim Senenan di Pengajian Seninan Musholla Baitul Huda Kelurahan Gisikdrono Jalan Mintojiwo Dalam 1 Semarang. Majlis taklim ini merupakan salah satu majelis taklim yang memiliki banyak kegiatan/aktivitas baik keagamaan maupun sosial. Program pengabdian tentang upaya penguatan hak asasi perempuan dan kesetaraan gender melalui dialog warga ini dilaksakan selama 3 (tiga) bulan, yaitu tehitung sejak bulan Juni sampai dengan Agustus 2016.

\section{Proses Kegiatan Pendampingan}

Kegiatan pendampingan dilakukan dalam beberapa tahap meliputi tahap persiapan, observasi dan pelaksanaan program. Pada tahap persiapan, tim pengabdi melakukan persiapan-persiapan untuk pelaksanaaan program. Tim bersama masyarakat melakukan focus discussion group (FGD). FGD merupakan bagian dari diskusi akademik untuk mematangkan proposal yang sudah disusun oleh tim. Tim mengundang para dosen Fakultas Dakwah dan Komunikasi dalam kegiatan FGD. Tahap persiapan kedua melakukan koordinasi tim. Koordinasi tim dilakukan dalam rangka untuk merancang jadwal dan menyusun tahapan program yang akan dilakukan. Tahap observasi awal dan perijinan. Observasi dilakukan untuk memperoleh gamrana umum tentang lokasi program yang bertempat di kelurahan Gisik Drono. Observasi dan perijinan dilakukan dengan berkoordinasi dengan Bapak Lurah setempat dan pengurus majlis taklim. Tahap ketiga adalah pelaksanaan program. Program dialog warga dilakukan selama kurang lebih 2 bulan dengan jumlah pertemuan sebanyak enam kali. Per- 
temuan pertama dilaksanakan pada hari Senin, tanggal 18 Juli 2016. Pada pertemuan ini, tim melakukan gambaran awal tentang program yang akan dilaksanakan sekaligus merencanakan jadwal kegiatan yang akan dilakukan bersama-sama. Berdasarkan pertemuan tersebut disepakati bahwa program tersebut akan dimulai pada malam Jumat berikutnya yang akan dihadiri oleh gabungan dari pengajian Ibu Senenan dan pengajian Bapak-bapak Malam Jumat. Pada pertemuan ini terlihat calon peserta antusias untuk mengikuti program tersebut.

Pertemuan kedua dilaksanakan pada hari Kamis malam Jumat, tanggal 21 Juli 2016 sehabis shalat Maghrib bertempat di Mushala Baitul Huda. Pertemuan kedua menghasilkan gambaran umum program dan sesi perkenalan. Gambaran program dimaksudkan bahwa fasilitator mengantarkan sesi dengan memberikan gambaran umum program pengabdian yang dilakukan yaitu tentang penguatan hak asasi perempuan serta menyampaikan tujuan kegiatan tersebut. Sesi perkenalan, fasilitator meminta setiap peserta untuk memperkenal diri dengan menuliskan nama panggilan dan kelebihan yang dimiliki pasangan/anggota keluarga pada selembar kertas (peserta terlihat antusias dalm sesi ini karena biasanya mereka mengikuti pengajian yang hanya menggunakan metode ceramah). Ketiga perkenalan diri. Masing-masing memperkenalkan diri dan menyebutkan kelebihan yang dimiliki pasangannya. Tujuan dari sesi ini adalah agar peserta lebih melihat pada sisi kelebihan yang dimiliki paangan, bukan sebaliknya (melihat kekurangannya). Harapannya dengan mengingat kelebihan yang dimiliki pasangan masing-masing akan menumbuhkan penerimaan dan rasa bersyukur. Hasil dari perkenalan menunjukkan bahwa masing-masing individu memiliki potensi dan kekuatan. Tahap selanjutnya setelah sesi perkenalan, adalah menayangkan sebuah film pendek. Film tersebut menggambarkan tentang aktivitas yang dilakukan oleh seorang istri (ibu) dan suami (ayah) sejak bangun tidur sampai dengan tidur kembali. Diperlihatkan dalam film tersebut, aktivitas istri sejak bangun pagi (sebelum suaminya bangun) sudah mulai bekerja untuk membersihkan rumah, memasak, sampai dengan mengurus anak-anak yang berjumlah tiga orang (salah satunya balita/bayi). Sang ibu sangat sibuk mempersiapkan keperluan semua anggota keluarga sebelum mereka berangkat berkerja. Sedangkan sang suami/ayah begitu bangun tidur langsung nonton TV sambil membaca koran dan menikmati kopi dan sarapan yang dihidangkan oleh istrinya sementara si isteri masih sibuk dengan urusan dapurnya dan mengurus 
balitanya. Sementara istrinya sibuk dengan pekerjaan rumahnya, sang suami terlihat dengan santainya nonton televisi (TV) tanpa berusaha membantu pekerjaan istrinya. Setelah semua pekerjaan selesai, keduanya berangkat berkeja, sang ibu membawa dua anaknya untuk diantar ke sekolah sambal membawa tentengan tas yang berat, sementara sang ayah hanya menggandeng anak laki-lakinya yang sudah besar. Adegan berikutnya, terlihat kegiatan sang ibu di pabrik yang sibuk menjahit dengan tingkat konsentrasi yang cukup tinggi, sedangkan di sisi yang lain terlihat suami yang bekerja sebagai penjaga alat berat yang masih bisa bersantai sambal merokok. Adegan berikutnya, Nampak sang isteri menerima upah sebesar sebuah koin sedangkan suami memperoleh upah dua buah koin. Setelah itu terlihat bahwa hasil kerja suami digunakan untuk makan-makan dengan teman-temannya, sedangkan upah hasil kerja istri digunakan untuk membeli susu dan keperluan rumah tangga yang lain. Setelah itu keduanya terlihat pulang kerja, istri menjemput kedua anaknya, dan suami menjemput anak laki-lakinya. Setibanya di rumah sang suami langsung istihat, makan, mandi dan tidur, sedangkan sang istri begitu pulang masih sibuk dengan pekerjaan rumah, membereskan dapur, memasak, memandikan dan mengurus anak-anak. Terlihat semua sudah tidur, tapi sang ibu masih terjaga dan melanjutkan aktivitas dengan menjahit baju anaknya, dan akhirnya menjelang tengah malam baru tertidur. Setelah itu terlihat adegan bahwa sang istri bermimpi, dalam mimpinya ia membayangkan bahwa suaminya mau membantu pekerjaan rumahnya, mau membantu mengasuh anaknya, dan lebih menyayangi dirinya. Dan film itu berakhir dengan tulisan "Impossible Dream".

Setelah menonton film tersebut, fasilitator memandu diskusi dan mereview pendapat peserta tentang film tersebut. Terdapat dua respon warga mengenai film yang ditayangkan bersifat positif dan negatif. Respon positi ditunjukkan karena warga masih menganggap bahwa pekerjaan rumah adalah pekerjaan seorang istri, sedangkan respon negatif ditunjukkan bahwa telah ada kesadaran warga bahwa laki-laki dan perempuan memiliki peran sosial yang sama. Tidak ada yang lebih tinggi kedudukannya dalam berumah tangga. Fasilitator memandu untuk mendiskusikan tentang beban ganda perempuan dan bagaimana seharusnya tanggung jawab, hak dan kewajiban suami. Sesi diskusi/tanya jawab. Sesi ini mendiskusikan tentang persoalan-persoalan yang dirasakan peserta dalam kehidupan rumah tangganya. Ada seorang ibu yang menanyakan tentang hadis yang berisi 
bahwa sebaik-baiknya sholat perempuan adalah di rumahnya. Mengingat persolan tersebut membutuhkan diskusi yang lebih panjang maka akan didiskusikan pada pertemuan selanjutnya.

Pertemuan ketiga dilaksanakan pada Sabtu Malam, tanggal 30 Juli 2016 (pk. 19.00 - 21.00). pertemuan ketiga melakukan review materi sebelumnya, yaitu tentang pentingnya menerima kekurangan pasangan dengan lebih mengingat pada kelebihan yang dimiliki pasangannya. Menayangkan dan menyaksikan bersama-sama sebuah film pendek tentang kekerasan dalam rumah tangga. Dalam film tersebut menggambarkan tentang banyaknya kekerasan yang sering dilakukan suami pada isterinya. Pertemuan ketiga mendiskusikan tentang pesan-pesan yang terkandung dalam film tersebut, apa penyebabnya, dan bagaimana mencegahnya. Fasilitator meminta peserta untuk bersama-sama menyanyikan lagu Yogyakarta yang di dalamnya mengandung maksud tentang kelebihan yang dimiliki kota tersebut. Lirik laku Yogyakarta, diganti dengan Gisik Drono. Selanjutnya mereview tentang kandungan/maksud yang terkandung dalam lagu tersebut mengenai poligami.

Dari kegiatan ini masyarakat memilikipemahaman mengenai bagaimana sejarah poligami (perlu menelusuri poligami yang dilakukan Rasulullah). Mengapa rasulullah melakukan poligami, bagaimana dampak poligami masa rasulullah. Persoalan poligami muncul akibat dari pemahaman mengenai adanya penafsiran yang sepihak tentang ayat al-Qur'an QS. al-Nisa' ayat 4. Belum ada penafsiran yang komprehensif mengenai QS. al-Nisa' ayat 4. Perlu kajian secara komprehensip berdasarkan pada asbab al-nuzul dan asbab al-wurud-nya. nya merupakan peringatan bagi wali anak yatim untuk berlaku adil/lihat konteks ayat tersebut. Ayat lain mengenai poligami terdapat dalam QS. al-Nisa' ayat 129 menyebutkan tentang sulitnya untuk berlaku adil bagi suami yang poligami (meskipun ia berusaha dan sangat menginginkannya), karena adil secara hati sangat sulit/tidak mungkin. Mendiskusikan tentang kriteria dalam memilih pasangan/mencarikan jodoh untuk anaknya. Ada empat hal 1) karena hartanya, 2) karena nasabnya, 3) karena ketampanan/ kecantikannya/ rupanya, 4) karena agamanya. Dari keempat hal tersebut pilihlah karena agamanya. Karena: 1) harta, tidak akan selamanya ada, 2) belum tentu keturunan menjamin, 3) bisa berubah, 4) pondasi dalam membangun keluarga.

Pertemuan keempat dilaksanakan pada hari Senin Malam, 1 Agustus 2016 bertempat di Musholla Baitul Huda dengan tema "Meraih Mimpi'. 
Kegiatan ini diawali dengan refleksi materi minggu lalu, dilanjutkan dengan membuat buku mimpi yang menggambarkan tentang keluarga yang diharapkan/diidam-idamkan. Buku mimpi dibuat dengan menempelkan potongan-potongan gambar dari koran/majalah yang sudah disediakan kemudian menuliskan maksud dari gambar tersebut. Setelah masing-masing peserta sudah membuat buku mimpi, masing-masing diminta untuk menunjukkan gambar tersebut kepada peserta yang lain dan menyampaikan mimpi yang ingin digapai yaitu keluarga sakinah mawaddah wa rahmah. Mendiskusikan bagaimana meraih mimpi menjadi hal penting dalam kegiatan. Fasilitator mengeksplorasi bagaimana upaya meraih mimpi tersebut.

Pertemuan kelima dilaksanakan pada Senin, 15 Agustus 2016 diawali dengan review tentang materi sebelumnya. Fasilitator mengeksplorasi tentang rencana tindakan yang sudah disusun masing-masing peserta untuk meraih mimpinya. Peserta menyampaikan tindakan yang sudah dilakukan dalam seminggu terakhir untuk mewujudkan mimpi yang telah ditulis pada pertemuan sebelumnya. Meskipun langkah yang dilakukan baru merupakn tahapan awal untuk meraih mimpi tersebut, namun sudah menampakkan hasil dalam rangka untuk meraih mimpi tersebut. Mendiskusikan tentang: kesetaraan gender dalam Islam. Fasilitator menyampaikan tentang konsep Islam tentang kedudukan laki-laki dan perempuan, terutama tentang tafsir ayat-ayat yang seringkali menjadikan bias gender (adapun materi sebagaimana terlampir). Peserta menanyakan tentang ayat yang menyebutkan bahwa laki-laki adalah 'qawwam' bagi perempuan, dan selanjutnya mendiskusikannya.

\section{Strategi Penguatan Kapasitas Hak Asasi Perempuan dan Kesetaraan Gender di Gisikdrono}

Strategi penguatan kapasitas penguatan hak asasi perempuan dan kesetaraan gender dilakukan melalui Model dialog warga. Metode ini bertujuan untuk mengembangkan kompetensi komunitas dalam menangani isu hak asasi perempuan dan kesetaraan laki-laki dan perempuan yang mereka anggap paling penting. Salah satu Prinsip dasar dialog warga selalu berbasis kepada hak asasi, kesetaraan, apresiatif, berbasis asset masyarakat, memberdayakan, berkelanjutan, berorientasi perubahan, menggunakan bahasa/ istilah local, dan bukan merupakan proyek. Pendampingan yang dilakukan pada warga kelurahan Gisikdrono sejalan dengan kebutuhan 
masyarakat akan pemenuhan hak asasi perempuan yang saat ini masih diperjuangkan. Isu-isu tentang kekerasan dalam rumah tangga, beban ganda perempuan, pemarginalan ekonomi dan lain sebagainya merupakan persoalan yang masih sering terjadi.

Program pengabdian yang dilakukan selama kurang lebih dua bulan berupaya untuk membangkitkan kesadaran masyarakat agar mereka mengetahui tentang hak-haknya sebagai warga negara dan warga masyarakat yang seringkali belum mereka terima (khususnya bagi perempuan). Misalnya yang berkaitan dengan persoalan tanggung jawab dalam mengurus perkerjaan rumah tangga dan mengasuh anak. Seringkali masyarakat menganggap bahwa tugas mendidik dan mengasuh anak adalah semata mata tugas perempuan (sebagaimana diungkapkan Ibu A pada pertemuan kedua). Demikian halnya dengan tugas mengurus pekerjaan rumah tangga yang seringkali dibebankan hanya kepada perempuan (Ibu C, pertemuan kedua). Padahal sesungguhnya kedua orang tua memiliki tanggung bersama dalam mendidik, merawat, dan membesarkan anak-anaknya.

Proses pendampingan ini dilakukan dengan menggunakan metode dialog warga yang terdiri dari enam langkah yaitu: pertama, persiapan; kedua, mengenali kekuatan yang ada; ketiga, mendekati mimpi; keempat, menyusun rencana aksi; kelima, merayakan mimpi bersama, dan keenam, implementasi rencana aksi dan pemantauan. Adapun tahapan pada masingmasing langkah tersebut meliputi tujuh tahapan, yaitu: 1) persiapan, 2) imajinasi, 3) pengungkapan, 4) dialog, 5) rangkuman, 6) penutup, dan 7) refleksi. Berdasarkan langkah-langkah yang telah ditetapkan tersebut, pelaksanaan pendampingan yang dilakukan di kelurahan Gisikdrono.

Tahap Pertama, tahap persiapan; tahap ini dilakukan dengan beberapa kegiatan yaitu, melakukan observasi dan proses perijinan, melakukan FGD dengan akademisi, dan merancang jadwal kegiatan dan materi kegiatan. Kedua, tahap mengenali kekuatan yang ada; dilakukan dengan menggali potensi yang dimiliki warga. Dalam hal ini warga diminta untuk mengenali keunggulan dan kekuatan yang dimiliki dirinya, pasangan, dan keluarganya. Dengan menggali kekuatan tersebut warga diharapkan mampu merencanakan 'mimpi' untuk masa depannya. Ketiga, tahap mendekatkan mimpi; dilakukan dengan kegiatan dimana warga diminta untuk membuat buku mimpi yang berisi tentang harapan yang ingin diraihnya dalam jangka waktu tertentu. Hal ini dilakukan untuk memperjelas arah dan cita-cita yang ingin diraih terutama yang berkaitan dengan relasi dalam keluarga (kehidup- 
an rumah tangga). Keempat, tahap menyusun rencana aksi. Setelah menyusun mimpi yang akan diraih dan juga mengetahui kekuatan yang dimiliki, pada tahap ini warga diminta untuk menyusun rencana/tindakan apa yang akan dilakukan untuk menggapai mimpi tersebut. Tujuannya untuk mendekatkan atau memudahkan warga dalam menggapai mimpi tersebut. Kelima, tahap merayakan mimpi bersama. Pada tahap ini, diharapkan warga telah merayakan mimipi yang telah diraihnya, namun mengingat durasi dan waktu pendampingan yang relatif singkat, maka tahap merayakan mimpi ini dilakukan dengan mengeksplorasi tentang bagaimana progress yang sudah dilakukan dalam rangka meraih mimpi tersebut, jadi masih berupa progress sementara, bukan hasila akhir. Keenam, tahap implementasi rencana aksi dan pemantauan. Hal ini dilakukan dengan melakukan refleksi pada pertemuan terakhir untuk mengetahui penacapaian dan perubahan yang dialami oleh warga. Refleksi dilakukan untuk mengukur perubahan baik yang berkaitan dengan dimensi pengetahuan, sikap, maupun psikomotorik (perilakunya). Adapun langkah-langkah pada masing-masing tahap telah dilakukan dengan mempertimbangkan situasi dan kondisi peserta pelatihan/warga. 1) langkah persiapan dilakukan oleh tim setiap kali akan melakukan pendampingan dengan merencanakan jadwal, materi, dan perlengkapan apa saja yang dibutuhkan. 2) langkah imajinasi; dilakukan dengan meminta peserta untuk membayangkan situasisituasi tertentu sesuai dengan topik yang sedang didiskusikan, 3) langkah pengungkapan; dilakukan dengan meminta peserta untuk terlibat aktif dan menyampaikan apa yang dipikirkan, dirasakan, dana tau dialami, 4) langkah dialog; dilakukan dengan mendialogkan persoalan-persoalan yang dilontarkan oleh peserta/persoalan-persoalan yang terjadi dalam lingkungan masyarakat sekitar, 5) langkah rangkuman; dilakukan dengan merangkum setiap hasil diskusi yang telah dilakukan, 6) langkah penutup, dilakukan setelah sesi tertentu berkahir, dan 7) langkah refleksi; dilakukan dengan meminta pendapat pada peserta tentang sesi/tahapan yang telah dilalaui, bagaimana perasaan yang dirasakan, dan bagaiman perubahan yang dialami setelah megikuti kegiatan tersebut.

\section{Analisis Hasil Kegiatan}

Penguatan hak asasi perempuan dan kesetaraan gender di Kelurahan Gisikdrono ini dilakukan dengan menggunakan metode dialog warga. Dialog warga mencoba lebih melakukan elaborasi atas kapasitas dan kepentingan komunitas. Asumsi utama adalah bahwa masyarakat telah me- 
miliki pengetahuan maupun pengalaman untuk mengatasi persoalanpersoalan yang menjadi keprihatinan bersama. Tujuan dialog warga adalah untuk mengembangkan kompetensi komunitas dalam menangani isu-isu hak asasi perempuan dan kesetaraan laki-laki dan perempuan yang mereka anggap paling penting.

Tahapan dalam dialog warga terdiri dari enam tahapan, yaitu; persiapan, mengenali kemampuan yang ada, mendekatkan mimpi, merencanakan rencana aksi, merayakan mimpi bersama, implementasi rencana aksi dan pemantauan. Berdasarkan tahapan tersebut, pendampingan yang telah dilakukan telah melalui keenam tahap tersebut. Berdasarkan tahapan tersebut, output yang diperoleh dari subyek dampingan meliputi tiga hal, kesadaran tentang menghargai hak asasi perempuan, nilai-nilai kesetaraan dan keadilan gende, dan meningkatnya kualitas SDM, khususnya kaum perempuan. Perubahan pemahaman masyarakat tentang kesadaran gender dilihat dari perbedaan pemahaman di awal proses pendampingan dibandingkan dengan refleksi pada akhir kegiatan. Pada awal pendampingan, diketahui bahwa sebagian peserta memiliki pemahaman yang 'bias gender'. Hal ini ditunjukkan dengan beberapa hal diantarnya sebagian peserta beranggapan bahwa tugas-tugas kerumahtanggaan hanya dibebankan kepada perempuan/istri; sebagian peserta meyakini tentang penafsiran beberapa ayat al quran dan hadis yang bias gender, misalnya penafsiran tentang "arrijalu qawwamuna 'alannisa", hadis tentang keutamaan sholat bagi wanita di rumah, hadis tentang kebolehan puasa sunnah atas ijin suami, ayat tentang kebolehan suami melakukan kekerasan pada istri, dan lain sebagainya; Sebagian peserta beranggapan bahwa tugas merawat dan mendidik anak hanya dibebankan pada istri.

Berbagai anggapan-anggapan tersebut disampaikan oleh peserta pada awal pertemuan/awal proses pendampingan. Setelah melalui proses pendampingan selama kurang lebih dua bulan, para peserta kemudian memiliki perspektif yang lebih 'setara". Hal ini dapat dilihat dari tahapan dimana peserta diminta untuk mendekatkan mimpi dan melakukan rencana aksi, nampak bahwa mereka sudah memiliki rencana untuk melakukan perubahan dalam rangka untuk meraih mimpinya mewujudkan keluarga yang sakinah. Berdasarkan refleksi dan evaluasi pada akhir tahap pendampingan juga diketahui bahwa peserta memiliki komitmen dan semangat untuk melakukan diseminasi atau dalam bahasa jawanya 'gethok tular' ilmu yang sudah diperoleh selama sesi pendampingan. 
Adapun kendala yang diharapi selama proses pendampingan yaitu; kesulitan dalam menyesuaikan jadwal yang sudah ditetapkan tim dengan aktivitas warga; sebagian peserta tidak secara berkesinambungan mengikuti semua pertemuan/ semua sesi, sehingga dimungkinkan ada sebagian informasi yang terputus; Keterbatasan durasi setiap pertemuan, mengingat kegiatan tersebut dilakukan pada malam hari.

\section{Kesimpulan}

Upaya penguatan Hak asasi perempuan dan kesetaraan gender yang telah dilakukan di kelurahan Gisikdrono Semarang. Program pengabdian telah dilaksanakan sesuai dengan perencanaan dengan menggunakan metode dialog warga yang terdiri dari enam tahapan. Pelaksanan metode dialog warga sudah menerapkan prinsip dan metode fasilitasi yang menarik masyarakat sehingga peserta berperan aktif dalam kegiatan tersebut. Output yang dicapai dari kegiatan adalah timbulnya kesadaran. Tumbuhnya kesadaran masyarakat untuk menghargai hak asasi perempuan dan tumbuhnya kesadaran masyarakat tentang nilai-nilai kesetaraan dan keadilan gender. Rekomendasi yang dihasilkan dari program mendasarkan bahwa sebuah proses pendampingan membutuhkan waktu yang relatif lama dan membutuhkan kesinambungan, maka diperlukan program pendampingan yang bertahap dan berkesinambungan tidak hanya terbatas pada dua bulan saja melainkan multi years. Perlu monitoring lebih lanjut untuk mengetahui perkembangan subyek dampingan sehingga hasil yang sudah diperoleh tetap terjaga bahkan diupayakan mengalami peningkatan.]

\section{Daftar Pustaka}

Alami, Yasir, Jenis Kelamin Tuhan, Yogyakarta: Yayasan Kajian dan layanan Informasi untuk Kedaulatan Rakyat, 2002.

al-Bani, M. Nasarudin, Ringkasan Shahih Muslim, Jakarta: Gema Insani, 2005.

Buku 1, Bahan Informasi Pengarusutamaan Gender, Edisi ke-2, Apa Itu Gender?, Menteri Negara Pemberdayaan Perempuan RI, 2002.

Buku 2, Bahan Informasi Pengarusutamaan Gender, Edisi ke-2, Bagaimana Mengatasi Kesenjangan Gender, Menteri Negara Pemberdayaan Perempuan RI, 2002. 
Buku Referensi Pelatihan: Fakta dan Indikator Gender Tingkat Nasional, 4 Propinsi dan 16 Kabupaten/Kota Terpilih, Kementerian Pemberdayaan Perempuan, JCA dan UNFPA, 2003.

Echols, John M. dan Hasan Shadily, Kamus Inggris - Indonesia, Jakarta: Gramedia, 1995

Engineer, Asghar Ali, Pembebasan Perempuan, Yogyakarta: LKiS, 1999.

Fakih, Mansour, Analisis Gender dan Transformasi Sosial, Yogyakarta: Pustaka Pelajar, 1997.

Friedman, J., Empowerment: The Politics of Alternative Dewvelopment, Oxford: Blackwell, 1992.

Hadiati, Sri, dkk., Perencanaan SDM: Pendekatan Praktis Perencanaan SDM, Jakarta: LAN RI, 2005.

Hitti, Philip K., History of The Arabs,.New York: Palgrave Macmillan, edisi revisi ke-10.2002. Penerjemah: R. Cecep Lukman Yasin dan Dedi Slamet Riyadi. Jakarta:PT Serambi Ilmu Semesta. Cetakan II. 2006.

Kementerian Agama RI, Lajnah Pentashik al Quran, Jakarta, 2012.

Kementerian Pemberdayaan Perempuan dan Anak RI bekerjasama dengan GIZ melalui program SWR, Dialog Warga: Metode Penguatan Hak Asasi Perempuan dan Kesetaraan GenderBagi Kelompok Warga, Modul Dialog Warga, Kementerian Pemberdayaan Perempuan dan Anak RI, t.th.

Komnas perempuan, 2014, diakses 15 Maret 2016.

Lips, H.M., Sex and Gender; an Introductions, California: Mayfield Publishing Company, 1993.

Lips, Hillary M., Sex and Gender: An Introduction, London:May field Publishing Company, 1993.

Lutfiyah, Gender dan Makna Persamaan, Jumal Studi gender dan Anak SAWWA, Vol. 4, No. 1, Oktober 2010.

Maba, Ghufron, Kamus Lengkap Inggris Indonesia, Surabaya: Terbit Terang, t.th.

Mazaya, Viky, Kesetaraan Gender dalam Perspektif Sejarah, Jurnal Studi Gender dan Anak, SAWWA, Vol. 9, No. 2, April 2009.

Megawangi, Ratna, Membiarkan Berbeda, Bandung: Mizan, 1999.

Modul Pelatihan, Keadilan dan Kesetaraan Gender untuk BUMN/BUMD dan Perusahaan Swasata Menteri Negara Pemberdayaan Perempuan, Deputi Bidang Kesetaraan Gender bekerjasama dengan Bangun Mitra Sejati, 2001. 
Muawanah, Elfi, Menuju Kesetaraan Gender, Malang: Kutub Minar, 2006.

Mulia, Siti Musda, Kekerasan tehadap Perempuan mencari Akar Kekerasan dalam teologi, SAWWA Jurnal Studi Gender dan Anak, Vol. 3, No. 1, 2008.

Muthahari, Murtadha, Hak-hak Perempuan dalam Islam, Jakarta: Lentera, 1995.

Narwoko J. Dwi, dan Bagong Suyanto, Sosiologi Teks Pengantar dan Terapan, Jakarta: Kencana, 2010.

Nugroho, Rian, Gender dan Strategi Pengarustamaan di Indonesia, Yogyakarta: Pustaka Pelajar, 2008.

Pasaribu, Vera A. R., Kesetaraan dan Keadilan Gender, Laporan Penelitian, FISIP Universitas HKBP Nommensen, Medan, 2006.

Rachmadewi, dkk., Studi Evaluasi Pelaksanaan Program Kesetaraan dan Keadilan Gender (KKG) Sektoral di Tingkat Pusat, Propinsi Jawa Timur dan Sumatera Barat, Laporan Penelitian, Puslitbang KS dan Peningkatan Kualitas Perempuan, Jakarta, BKKBN, 2000.

Rachman, Budhy Munawar, Islam Pluralis Wacana Kesetaraan Kaum Beriman, Jakarta: Paramadina, 2001.

Rahardjo, Mudjia, Relung-Relung Bahasa, Yogyakarta: Aditya Media, 2002.

Ridjal Fauzie, Dinamika Gerakan Perempuan di Indonesia, Yogyakarta: Tiara Kencana, 1993.

Ritzer, George, and Douglas J. Goodman, Modern Sociological Theory, 1996.

Sadli, Saparinah, Berbeda tetapi Setara: Pemikiran tentang Kajian Perempuan. Jakarta:PT Kompas Media Nusantara. 2010.

Shihab, Quraish, Wawasan al-Qur'an Tafsir Tematik atas Pelbagai Persoalan umat, Bandung: Mizan, 1996.

Siroj, Said Aqil, Tasawuf Sebagai Kritik Sosial, Bandung: Mizan, 2006.

Subhan, Zaitunah, Perempuan dan Politik dalam Islam.Yogyakarta: Pustaka Pesantren, 2004.

Syamsuddin, Arif, "Wanita dan Keluarga Citra Sebuah Peradaban". Jurnal AlInsan, Kajian Islam, Jakarta: Lembaga Kajian dan Pengembangan Al Insan, Vol. 2, No. 3, 2006.

Thornham, Sue, Teori Feminisme dan Cultural Studies, Yogyakarta: Jalasutra, 2010.

Trianto, Teguh, "Relasi Gender dalam Bingkai Budaya Cablaka", Yinyang, Vol. 7, No. 2, Juli-Desember 2012 
Umar, Nasaruddin, Argumen Perspektif Gender dalam Al-Qur'an, Jakarta: Kencana, 2009.

www.detik.com, diakses 15 Maret 2016. 
